\title{
KARAKTERISTIK SOSIAL EKONOMI MASYARAKAT PETANI KECAMATAN BANDAR DALAM SISTEM LIVELIHOOD PEDESAAN
} M. Rosyid ${ }^{\text {a }}$ I.Rudiarto ${ }^{\text {b }}$

\author{
${ }^{a}$ Universitas Diponegoro, Indonesia, email: Ocid kuma@yahoo.com \\ ${ }^{b}$ Universitas Diponegoro, Indonesia, email: irudiarto@yahoo.com
}

\begin{abstract}
Article Info;
Abstract: Socio-economic position in terms of development generally to see how big the level

Received: 8 September 2014 of well-being of an area where it can be seen from the potential and the resources therein.

in revised form:

17 September 2014 with is dominated by the agricultural sector (35\% of the total areadistricts) can be found that most of the people working with depends on the utilization of natural resources. Not only that the quality of human resources became milestones in the progress of development.The purpose of this research is to identify the characteristics of the social and economic conditions

Accepted:

20 September 2014 of society rural farmers in rural Livelihood systems associated with education, income and the type of activities to the resources in Bandar. By using a quantitative approach supported by spatial analysis has focused on the potential, problems, and the amount of ownership of

Available Online: 1 October 2014

Keywords:

Natural Resources, Rural Assets and Access, Rural Livelihood Systems. community resources. In the system of Livelihood, is divided into five socio-economic livelihood assets where power access owned by Bandar Sub-district has a maximum value of human resources, subsequently followed by physical capital and natural resources capital. While the condition of two other assets that financial and social capital only has a value that is less than maximum/lower. It is characterized by a low level ofeducation, low-income family per capita income amounting to Rp. 5.399 .345 per year or were under the standard earnings Batang are mostly subsistence farmers patterned or does not make the commercial fields as agriculture and lacking the proper functioning of social groups in both averaging - align the farming community are below the poverty line. Later research is expected to provide a source of information and knowledge about the patterns of resource utilization and socio economic characteristics in Bandar describing existing condition so that the country can be used as a reference and referral information to further research.
\end{abstract}

Info Artikel;

Diterima:

8 September 2014

Hasil Revisi :

17 September 2014

Disetujui:

20 September 2014

Publikasi On-Line: 1 Oktober 2014

\section{Kata kunci:}

Sumber Daya, Aset Dan Akses Pedesaan, Sistem Livelihood Pedesaan.
Abstrak: Kedudukan sosial ekonomi pada isitilah pembangunan umumnya untuk melihat seberapa besar tingkat kesejahteraan suatu daerah dimana dapat dilihat dari potensi dan kualitas sumber daya didalamnya. Kecamatan Bandar merupakan wilayah pedesaan dengan kondisi geografis pegunungan dan pengairan yang baik dengan didominasi oleh sektor pertanian (35\% dari total luas area kecamatan) dapat dikatagorikan bahwa sebagian besar masyarakatnya berkerja dengan bergantung pada pemanfaatan sumber daya alam. Tidak hanya itu kualitas sumber daya manusia pun menjadi tolak ukur dalam kemajuan pembangunan. Tujuan penelitian ini yaitu mengidentifikasi kondisi karakteristik sosial dan ekonomi masyarakat petani pedesaan dalam sistem Livelihood pedesaan terkait dengan pendidikan, pendapatan dan jenis aktifitas terhadap sumber daya di Kecamatan Bandar. Dengan menggunakan pendekatan kuantitatif didukung oleh analisis spasial dalam penyajiannya difokuskan kepada potensi, masalah dan jumlah kepemilikan sumber daya masyarakat. Dalam sistem Livelihood, sosial ekonomi dibagi menjadi lima aset penghidupan dimana kekuatan akses yang dimiliki oleh Kecamatan Bandar memiliki nilai maksimal terhadap sumber daya manusia, selanjutnya diikuti dengan modal fisik dan modal sumber daya alam. Sedangkan kondisi dua aset lainnya yaitu modal finansial dan sosial hanya memiliki nilai yang kurang maksimal/rendah. Hal tersebut ditandai dengan rendahnya pendidikan, berpendapatan rendah dengan pendapatan keluarga perkapita sebesar Rp. 5.399 .345 pertahun atau berada dibawah standar penghasilan Kabupaten Batang, sebagian besar petaninya berpola subsisten atau tidak menjadikan pertanian sebagai ladang komersial dan kurang berfungsinya kelompok sosial secara baik membuat rata - rata masyarakat petani berada dibawah garis kemiskinan. Penelitian ini diharapkan dapat memberikan sumber informasi dan pengetahuan tentang pola pemanfaatan sumber daya dan karateristik sosial ekonomi di Kecamatan Bandar yang menggambarkan kondisi eksisting pedesaan sehingga dapat digunakan sebagai acuan informasi dan arahan penelitian selanjutnya. 


\section{PENDAHULUAN}

Masyarakat pedesaan pada umumnya adalah masyarakat yang menggunakan sumberdaya alam pada bidang agraris dimana oleh masyarakat pedesaan secara turun temurun melakukan aktifitas pada sektor pertanian. Keberadaan sumberdaya alam yang digunakan dipengaruhi oleh jumlah penduduk dan pola konsumsi penduduk terhadap sumberdaya tersebut. Tidak hanya itu sumberdaya dibatasi oleh lingkungan fisik serta kondisi geografis, pengelolaan sumberdaya yang tidak tepat atau konsumsi yang berlebihan dapat menyebabkan berkurangnya sumberdaya baik secara jumlah maupun kualitas pemakaiannya. Suatu desa memiliki tanah yang subur dengan pengairan yang lebih, maka dapat dipastikan kalau secara ekonomi penduduk desa itu ekonominya lebih baik. Sebaliknya apabila lingkungan alamnya kurang menunjang, pertaniannya kurang subur, maka ekonomi penduduk desa dapat dipastikan sebagian masyarakat desa masih hidup dalam kemiskinan dan keterbelakangan (Soepono, 1995). Dengan memiliki tanah yang tergolong subur yang meliputi dataran rendah sebagai areal persawahan dan untuk bagian perbukitan sampai pegunungan didominasi oleh tanaman pertanian seperti sayuran dan buah-buahan serta teh yang tersebar di 12 kecamatan, Kecamatan Bandar merupakan salah satu yang memiliki jumlah luasan areal pertanian terbesar di Kabupaten Batang.

Permasalahan yang ada seperti: BPS Kabupaten Batang menyebutkan pada tahun 2010 kemiskinan daerah Kabupaten Batang adalah mereka yang rata-rata tinggal di pedesaan dan yang bekerja sebagai petani yaitu sebesar $14,67 \%$ dari $16 \%$ total penduduk miskin Jawa Tengah. Hal ini perlu diteliti lebih lanjut mengingat sebagian besar masyarakat yang berada di wilayah pedesaan di Kabuten Batang adalah masyarakat yang beraktifitas pada bidang pertanian. Lahan yang mengecil karena banyaknya jumlah petani dapat menyebabkan petani membutuhkan lahan baru untuk meningkatkan penghasilan karena lahan yang sudah ada dirasa tidak lagi cukup memenuhi kebutuhan hidup mereka, berbagai cara di lakukan untuk mendapatkan lahan baru seperti membuka lahan dengan mengganti fungsi hutan menjadi area persawahan atau menjadikan lahan kosong tanpa penghuni yang jelas sebagai lahan garapan baru areal pertanian. Namun tidak dapat dihindari hal tersebut dapat mengundang permasalahan baru untuk petani, konflik terhadap kepemilikan lahan pernah terjadi di Kecamatan Bandar antara masyarakat petani swasta maupun BUMN dengan pihak perkebunan swasta (www.suaramerdeka.com, 2011).

Konflik tanah berbasis perkebunan dan kehutanan ini dikarenakan perebutan hak milik lahan yang terjadi karena ketidak harmonisan masyarakat dengan pemilik perusahaan. Penghasilan yang di dapat dari lahan masing-masing dinilai terlalu sedikit untuk menghasilkan keuntungan sehingga tidak dapat membantu meningkatkan perekonomian masyarakat yang berujung pada permasalahan sosial. Dalam sistem Livelihood pedesaan mengedepankan pendekatannya terhadap sektor ekonomi dan sosial menjadi menarik dikaji terkait kerentanan masyarakat petani terhadap kemiskinan yang dapat terjadi di Kecamatan Bandar. Kunci peningkatan kualitas hidup dalam sistem Livelihood pedesaan yaitu menitikberatkan aspek peningkatan taraf hidup masyarakat dengan meminimalisasi hambatan untuk mencapai tujuan pengoptimalan potensi akses dan aset yang dimiliki sehingga selanjutnya dapat diketahui bentuk dan karakteristik Kecamatan Bandar dalam sistem Livelihood pedesaan.

Wilayah yang akan di lakukan penelitian yaitu: ruang lingkup wilayah dalam penelitian merupakan Kecamatan Bandar adalah salah satu dari kecamatan di Kabupaten Batang Untuk lebih jelasnya dapat dilihat pembagian wilayah studi pada Gambar 1 di bawah ini. 
Gambar 1. Peta Administrasi wilayah Kecamatan Bandar (Bappeda Kabupaten Batang, 2010)

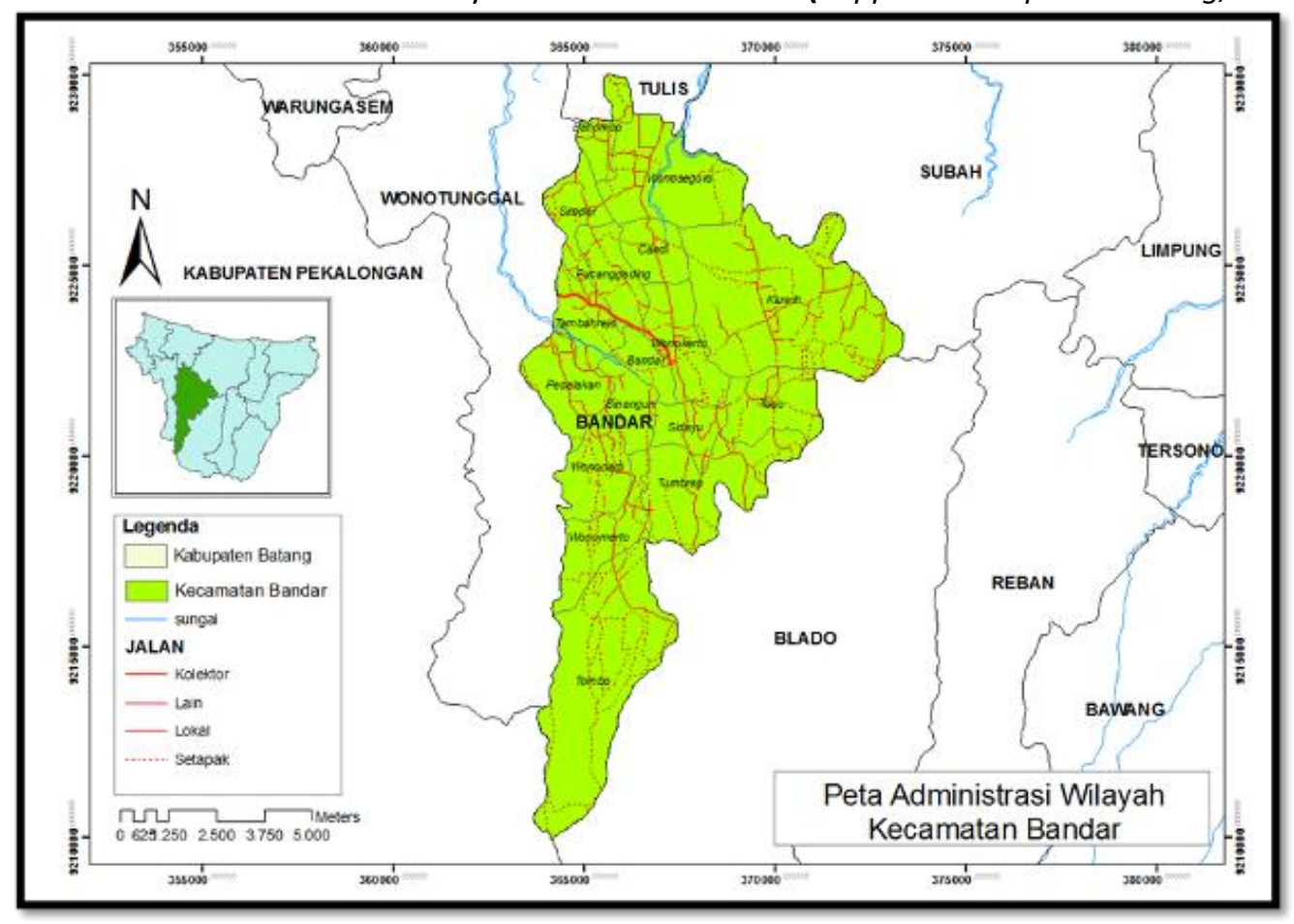

\section{DATA DAN METODE}

\subsection{Sistem Livelihood Pedesaan}

- Livelihood (Penghidupan)

Merupakan kemampuan, aset - baik material dan sosial sumber daya - dan kegiatan yang diperlukan untuk sarana hidup penduduknya (Food Agricultural Organization, 2008). Secara etimologis, Livelihood dapat diartikan sebagai aset atau modal (alam, manusia, finansial, sosial dan fisik), aktifitas dimana akses atas aset yang dimaksudkan diatas dimediasi oleh kelembagaan dan relasi sosial yang secara bersama mendikte hasil yang diperoleh oleh individu maupun keluarga (Saragih dkk, 2007).

- Akses

Merupakan suatu aturan dan norma sosial yang mengatur atau mempengaruhi kemampuan yang berbeda antara orang dalam memiliki, mengontrol, mengklaim atau menggunakan sumber daya seperti penggunaan lahan di pedesaan. Sedangkan menurut SAPA (Strategic Alliance For Proverty Alleviation, 2011) mengartikan akses sebagai hak masyarakat miskin untuk ikut menentukan alokasi sumberdaya yang non-tangible seperti bibit dan ternak, keuangan dan pasar yang memungkinkan mereka mengelola asset mereka untuk mencukupi kebutuhan hidup dan aset bisa diartikan sebagai hak penguasaan terhadap sumberdaya yang tangible seperti tanah.

- Konsep Sustainable Livelihood

Merupakan lima aset penghidupan yang dimiliki oleh setiap individu atau unit sosial yang lebih tinggi didalam upayanya mengembangkan kehidupannya yaitu: (1) humane capital, yakni modal yang dimiliki manusia; (2) social capital, adalah kekayaan sosial yang dimiliki komunitas; (3) natural capital, adalah persediaan sumberdaya alam; (4) physical capital adalah infrastruktur dasar dan memproduksi barang-barang yang dibutuhkan; serta (5) financial capital, yaitu sumber-sumber keuangan yang digunakan oleh masyarakat untuk mencapai tujuan-tujuan kehidupannya.

\subsection{Pentagon Asset Livelihood}

Kelima aset Livelihood tersebut dapat disederhanakan sebagai bentuk pentagon segi lima. Adapun kelima aset yang mempengaruhi Livelihood dapat diurai sebagai berikut :

\section{a. Sumber daya manusia (Human Capital)}


Human Capital dalam aset Livelihood dapat dilihat berdasarkan keterampilan, pengetahuan, kemampuan tenaga kerja dan kesehatan yang memungkinkan orang untuk mendapatkan pemasukan dari mata pencaharian. Sumber daya manusia ini didukung dari informasi yang diperoleh dari tingkat pendidikan dan pengetahuan penduduk lokalnya. Sedangkan jumlah dan kualitas tenaga kerjanya merupukan faktor dari: kesehatan dan tidak mengalami gizi buruk, komposisi dari rumah tangga, tingkat keterampilan, potensi kepemimpinan.

b. Modal sosial (Social Capital)

Didalam kehidupan masyarakat, masing-masing rumah tangga yang berbeda akan dihubungkan bersama oleh ikatan kewajiban sosial, hubungan timbal balik, kelompok dan ikatan formal sperti organisasi, kepercayaan dan hubungan yang saling mendukung.

c. Modal fisik (Physical Capital)

Merupakan infrastruktur dasar dan barang produsen yang diperlukan untuk mendukung mata pencaharian termasuk kedalamnya alat, infrastruktur seperti jalan, pelabuhan, bandara, serta fasilitas pasar (dalam artian yang lebih luas), air, atau fasilitas perawatan kesehatan yang akan mempengaruhi kemampuan orang lain untuk mendapatkan kehidupan yang layak.

d. Modal finansial (Financial Capital)

Mengacu pada sumberdaya keuangan yang digunakan seseorang untuk mencapai tujuan hidup mereka termasuk aliran dana dan saham yang dapat berkontribusi terhadap produksi dan konsumsi. Infrastruktur dasar dan barang produsen diperlukan untuk mendukung mata pencaharian bagi rumah tangga pedesaan seperti hasil poduksi pertanian. Mereka juga dapat menggunakan kredit formal dan informal untuk melengkapi sumber keuangan mereka.

e. Sumber daya alam (Natural Capital)

Bagi masyarakat pedesaan yang termasuk dalam sumberdaya alam antara lain tanah, air, sumber daya hutan, dan ternak. Tanah merupakan salah satu dari dua sumberdaya utama populasi pedesaan. Ketersediaan lahan tergantung pada banyaknya rumah tangga dan sistem kepemilikan lahan. Biasanya petani memiliki akses tanah melalui warisan, sewa tanah dan bagi hasil. Namun belakangan dalam kehidupan pedesaan masyarakat, distribusi tanah melalui warisan sudah mulai di tinggalkan. Oleh karenanya, mulai terdapat ekspansi lahan pertanian pada lahan-lahan lindung. Akibatnya jumlah pemilik lahan menurun dan rumah tangga yang tidak memiliki lahan meningkat.

Berikut merupakan gambar pentagon yang memperlihatkan bentuk dari segi lima aset Livelihood di atas:

Gambar 2. Pentagon Asset Livelihood $(F A O, 2008)$

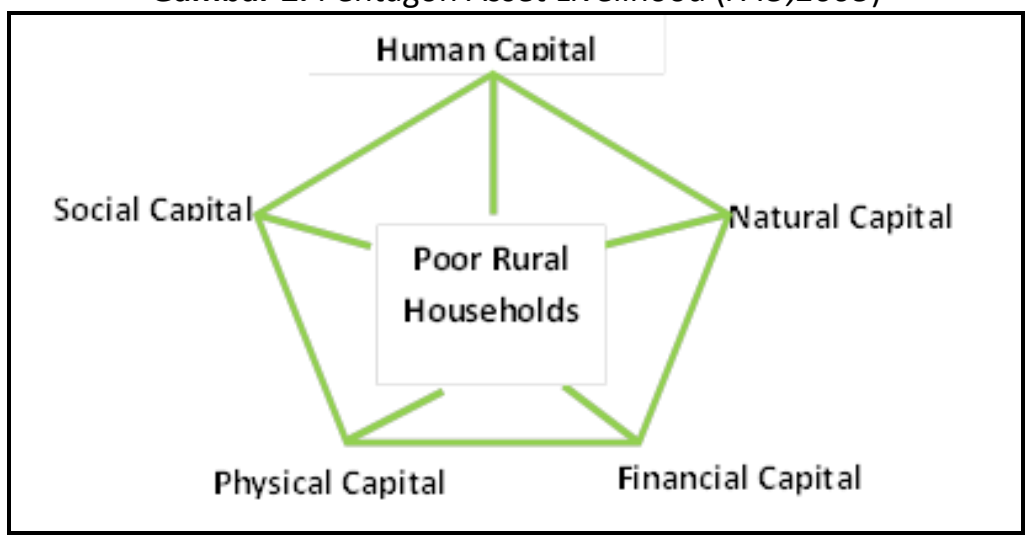

\section{METODOLOGI PENELITIAN}

Pendekatan penelitian yang digunakan dalam penelitian ini adalah pendekatan kuantitatif yang nantinya digunakan dalam menganalisis sosial ekonomi Kecamatan Bandar. Konsep juga dibangun dengan maksud memberikan pemahaman terhadap pengertian dan hubungan antar variabel, indikator, maupun skala pengukuran dalam penelitian yang dilakukan. Sebelum melakukan analisis dalam penelitian ini perlu diketahui variabel yang terkait dengan utilisasi sumberdaya pedesaan, aset dan akses sumberdaya, pola 
penggunaan sumberdaya, struktur pendapatan dan pengeluaran, dan sebaran spasial karakteristik sosial ekonomi.

Teknik pengumpulan data dalam penelitian ini dilakukan melalui dilakukan dua cara, yaitu teknik pengumpulan data primer melalui observasi lapangan dan kuesioner, serta teknik pengumpulan sekunder melalui kajian dokumen. Dalam penentuan jumlah sampel, Teknik pengambilan sampling yang telah ditentukan yaitu random sampling yang akan meyesuaikan ukuran sampel dengan kriteria-kriteria yang telah ditentukan sebelumnya. Berdasarkan rumus di atas, jumlah sampel dalam penelitian ini adalah 99 sampel dengan hasil perhitungan menggunakan rumus Slovin (Sangdji, et al., 2011) didapatkan hasil sebagai berikut:

$$
\mathbf{n}=\frac{\mathbf{9 2 2 1}}{\mathbf{1 + 9 2 2 1}(\mathbf{0 , 1})^{2} \mathbf{N}}=98,6 \approx 99 \text { sampel }
$$

Jenis analisis yang digunakan dalam penelitian, untuk menjawab pertanyaan dan mencapai tujuan penelitian sesuai dengan sasaran penelitian yang akan dicapai yaitu:

3.1 Analisis ketersediaan dan pola pemanfaatan sumberdaya dan hidup petani

Analisis ini dilakukan berdasarkan data primer dan skunder yang diperoleh melalui kuesioner dan kajian dokumen. Untuk mengolah hasil kuesioner digunakan statistik deskriptif. Pola yang dilihat didapat dari sikap atau cara petani memperlakukan faktor-faktor produksi yakni tanah dan sumber agraria, jenis komoditas yang di budayakan oleh petani serta aktifitas sosial ekonomi petani dalam mengelola sumberdaya. Dengan menggunakan analisis tersebut akan dihasilkan hasil analisis keterkaitan antara akses dan aset masyarakat berupa diagram yang dapat meramalkan kondisi serta pola sumberdaya.

3.2 Analisis Akses Masyarakat

Analisis yang bertujuan untuk mengetahui seberapa besar kemampuan masyarakat dalam memiliki dan mengoptimalkan aset sumberdaya sebagai sumber penghidupannya. Akses yang dimaksud adalah akses masyarakat terhadap sumberdaya produktif seperti lahan, permodalan (income), infrastruktur, pendidikan, kesehatan dan teknologi serta akses terhadap pelayanan publik dan pasar.

3.3 Analisis Aset Sumberdaya

Merupakan analisis untuk mengetahui seberapa besar modal masyarakat yang dibutuhlan dalam mencapai nilai-nilai livelihood agar tingkat kehidupannya dapat diarahkan menjadi postitif baik sekarang maupun yang akan datang. Hasil analisis nanti dapat menggambarkan seberapa besar modal masyarakat dilihat dari kepemilikan lima modal (fisik,sosial,finansial,sumberdaya manusia dan alam).

3.4 Analisis Pembeda Spatial

Analisis ini dilakukan untuk mengetahui gradasi karakteristik sosial ekonomi masyarakat pedesaan berdasakan atas hasil analisis yang telah dilakukan sebelumnya. Analisis ini memadukan data spasial dan informasi yang diperoleh dari analisis sebelumnya. Analisis ini menggunakan teknik interpolasi, dimana proses ini bertujuan untuk mengisi kekosongan data dengan menggunakan metoda tertentu untuk menghasilkan sebaran data uang kontinyu. Dalam analisis ini, data yang akan di interpolasi antara lain pendapatan, lahan, akses dan modal(Aset) yang nantinya diolah menggunakan teknik interpolasi yaitu kriging. Selama survei responden terhadap keluarga petani, posisi geografis masingmasing sampel rumah tangga responden dicatat dengan menggunakan alat bantu berupa GPS yang bertujuan mendapatkan titik-titik koordinat lokasi dari rumah responden yang disurvei. Selanjutnya hasil survei tersebut diolah dan dibuat menjadi bentuk spasial yang nantinya berupa peta dengan dilanjutkan dengan analasisis berupa peta gambaran spasial yang digunakan untuk menggambarkan karakteristik sosial ekonomi rumah tangga. 


\section{HASIL DAN PEMBAHASAN}

\subsection{Karakteristik Sumberdaya Manusia}

Dengan tingkat kepadatan penduduk berkisar antara $852 \mathrm{jiwa} / \mathrm{km} 2$ belum dapat dikatakan bahwa kondisi penduduk Kecamatan Bandar sangat padat dan belum memiliki jumlah yang cukup dalam ketersediaan jumlah penduduk. Dilihat dari usia produktifnya di Kecamatan Bandar jumlah penduduk berdasarkan kelompok umur dapat dilihat melalui tabel sebagai berikut:

Tabel 1. Jumlah penduduk Kecamatan Bandar berdasarkan kelompok umur (Analisis Penulis, 2014)

\begin{tabular}{|c|c|}
\hline Kelompok umur & Jumlah \\
\hline$<\mathbf{1 5}$ & 21109 \\
\hline $\mathbf{1 5}-\mathbf{6 0}$ & 37039 \\
\hline$>\mathbf{6 0}$ & 4334 \\
\hline
\end{tabular}

Maka berdasarkan tabel tersebut hasil perhitungan tingkat ketergantungan antara usia produktif terhadap usia non produktif adalah 1,45. Hal ini dapat diartikan setiap 1 orang pekerja/usia produktif hanya menanggung satu hingga dua orang. Berdasarkan hasil kuesioner yang didapat dari 99 keluarga, didapatkan jumlah total anggota keluarga keseluruhan yaitu sebanyak 372 jiwa yang tinggal bersama dalam satu rumah secara ekonomi untuk masing-masing keluarga di kawasan pedesaan Kecamatan Bandar didapat jumlah rata-rata perkeluarga yaitu antara 3 hingga 5 orang perkeluarga.

Tidak hanya itu saja, sebanyak 195 jiwa sudah mampu bekerja dibidang pertanian dan 16 diantaranya memiliki pekerjaan diluar sektor pertanian dengan rata - rata penghasilan tiap bulannya sebesar Rp.400.000,00 - Rp.1.000.000,00. Sebagian masyarakat memiliki pekerjaan tambahan untuk memperbaiki perekonomian mereka yaitu sebanyak $16 \mathrm{KK}$ dari jumlah total responden memiliki pekerjaan tambahan. Berdasarkan hasil dari kuesioner tingkat pendidikan masyarakat petani di Kecamatan Bandar memiliki rata - rata pendidikan sekolah dasar (SD), hal tersebut tentu saja mempengaruhi mutu pendidikan dan keterampilan dalam peningkatan taraf penghidupan.

\subsection{Karakteristik Lahan}

Di Kecamatan Bandar itu sendiri, hampir sebagian besar wilayahnya berupa lahan sawah yaitu dari total luas wilayah 7.332,80 Ha sebesar 2.414,24 Ha merupakan lahan pertanian (BPS Kabupaten Batang, 2010). Selain lahan pertanian, juga terdapat lahan berupa tegalan sebanyak $1.846,28 \mathrm{Ha}$, hutan rakyat 632,58 Ha dan juga perkebunan sebesar 797,87 Ha. Lahan - lahan tersebut merupakan milik warga maupun pihak swasta.

Ada berbagai jenis tanah yang dapat dijumpai di wilayah ini diantaranya yaitu jenis latosol coklat, asosiasi andosol coklat regosol coklat dan asosiasi letosol merah serta komplek latosol merah kekuningan yang merupakan jenis tanah dengan karakteristik wilayah pegunungan. Tidak hanya faktor lahan saja yang mempengaruhi jenis tanaman yang dibudidayakan tetapi juga faktor ketinggian dan kemiringan lahan dibeberapa kawasan Kecamatan Bandar juga menyebabkan perbedaan jenis tanaman yang dibudidayakan dalam bertani. Pada daerah ketinggian rendah, sebagian besar jenis tanaman yang diberdayakan adalah berupa padi maupun jagung. Sedangkan untuk daerah yang lebih tinggi sebagian besar jenis tanaman yang dinaman oleh masyarakat berupa sayur - sayuran seperti kubis, ubi-ubian, maupun teh yang penanamannya musiman sesuai dengan dengan kondisi iklim, cuaca dan pasar. 
Gambar 3. Peta jenis tanah (kanan), penggunaan lahan (tengah), dan topografi (kiri) Kecamatan Bandar (Analisis Penulis, 2014)

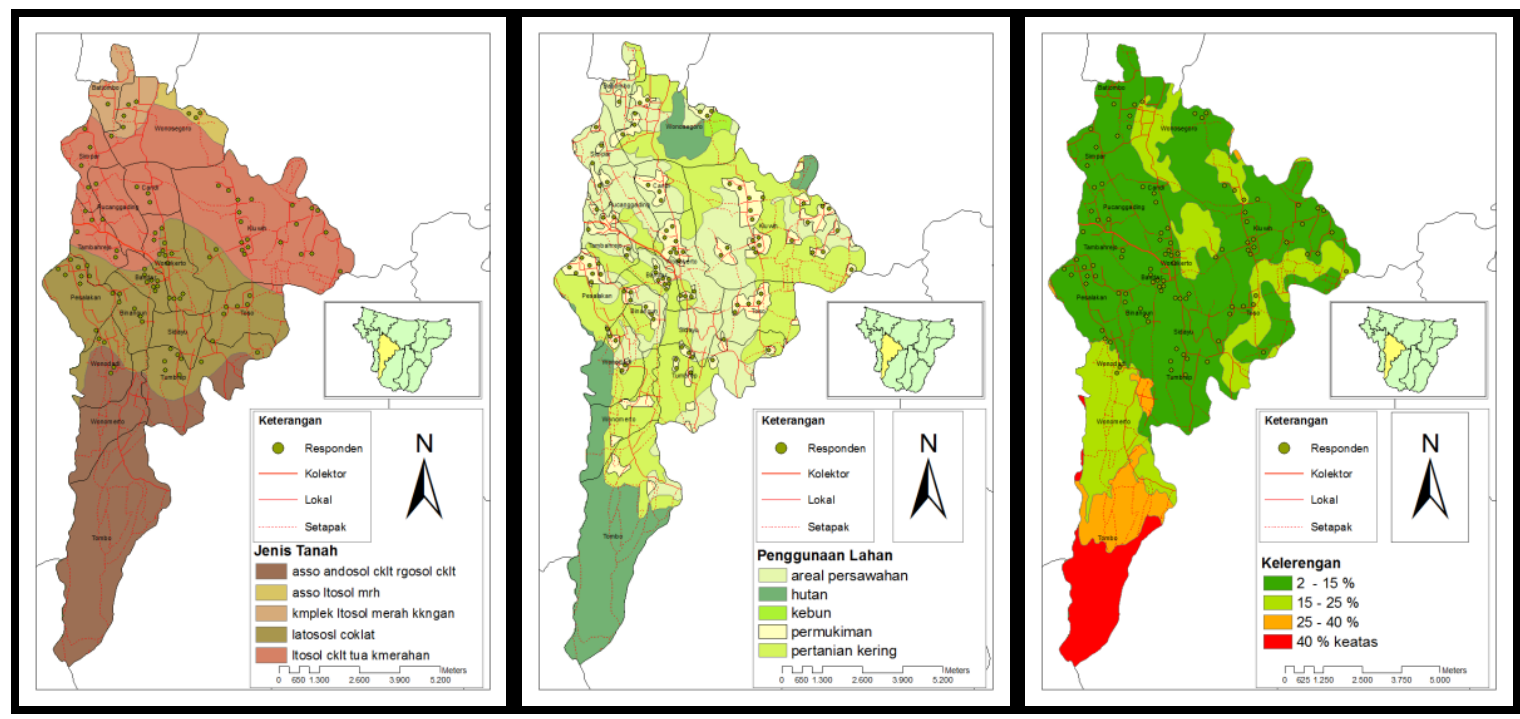

\subsection{Pola Penggunaan Hasil Sumberdaya Masyarakat Petani}

Tujuan utama masyarakat pedesaan pada umumnya adalah sebatas bagaimana memenuhi kebutuhan makan dan membesarkan anak sehingga tidak ada bentuk tuntutan lain untuk peningkatan kebutuhan hidup. Namun tidak semua petani hanya menjadikan hasil pertaniannya untuk sekedar kebutuhan pangan keluarga tetapi juga memanfaatkan penuh hasil dari lahan mereka untuk meningkatkan finansial yaitu pelakukan aktifitas ekonomi dari kegiatan agraria. Untuk melihat pola penggunaan hasil pertaniannya, Suhendar dan Yohana (1998) merumuskan tiga indikator untuk memahami pola subsistensi petani dengan dibedakan berdasarkan dari: sikap atau cara petani memperlakukan faktor -faktor produksi yakni tanah dan sumber agraria, besar kecilnya skala usaha petani dan jenis komoditas yang dibudidayakan petani. Berikut merupakan pola penggunaan hasil sumberdaya masyarakat petani di Kecamatan Bandar:

a. Jenis Pola Petani Subsisten

Dapat dikatakan bahwa petani subsisten Di Kecamatan Bandar memiliki karakteristik sebagai berikut: pada umumnya petani hanya memiliki skala lahan kecil dan tidak menanam jenis komuditas komersil untuk diproduksi; sebagian besar tidak memiliki pekerjaan lain selain dari sektor pertanian, tidak memiliki obsesi meningkatkan mutu hasil produksi dari lahan; kegiatan tanam menanam hanya sekedar kebutuhan dan tradisi turun temurun ataupun keterpaksaan pemenuhan kebutuhan hidup karena tidak memiliki kemampuan dan pengetahuan pada bidang lain; akses yang sulit terhadap kondisi perubahan harga pasar dimana keuntungan bergantung terhadap sikap para tengkulak yang mengontrol hasil produksi dari yang didapatkan.

b. Jenis Pola Petani Komersil

Petani komersial merupakan jenis petani yang berorientasi pada keuntungan maksimal hasil lahan. Petani jenis ini memiliki kemampuan sumberdaya agraria yang tinggi seperti seperti akses mereka terhadap sumberdaya alam, akses terhadap pasar dan lainnya. Petani komersial memiliki ciri mengejar profit guna memenuhi kebutuhan pasar seperti halnya melakukan penanaman tanaman dengan komoditas yang sedang dibutuhkan oleh pasar.

\subsection{Ketersediaan dan Pola Pemanfaatan Sumberdaya Livelihood}

Penghidupan atau bisa disebut livelihood merupakan istilah pembangunan yang menggambarkan kemampuan, kepemilikan serta aktifitas sebuah individu ataupun masyarakat terhadap modal/asset. Aset disini dapat disebut sebagai bentuk dari pengaruh kehidupan masyarakat pedesaan yaitu sumberdaya alam, sumberdaya masyarakat, modal finansial, modal fisik dan modal sosial yang nantinya dapat disederhanakan sebagai bentuk segi lima penghidupan atau petagon aset. 


\section{a. Pola Pemanfaatan Sumberdaya Alam (Natural Capital)}

Bagi masyarakat pedesaan jenis sumberdaya alam antara lain adalah tanah, air, sumber daya hutan, dan ternak. Tanah merupakan salah satu dari dua sumberdaya utama populasi pedesaan selain sumberdaya manusia itu sendiri. Berikut merupakan kondisi lahan masyarkat petani di Kecamatan Bandar.

Gambar 4. Status lahan masyarakat petani Kecamatan Bandar (Analisis Penulis, 2014)
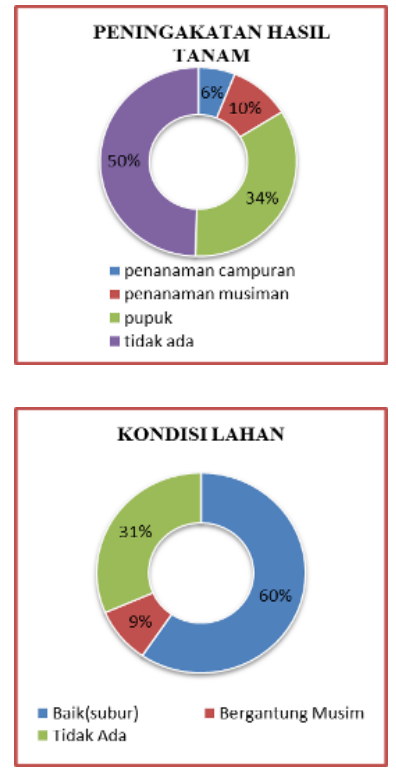

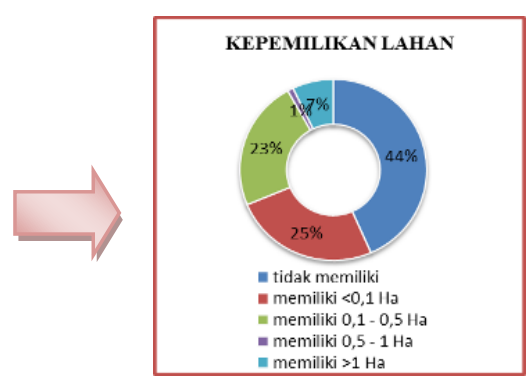

b. Sumberdaya Manusia (Human Capital)

Kecamatan Bandar memiliki kepadatan penduduk yang cukup padat, dengan rata - rata kepadatan penduduk antara $852 \mathrm{jiwa} / \mathrm{km} 2$ ketersediaan jumlah penduduk di Kecamatan Bandar termasuk sangat padat. Dengan kepadatan tinggi tersebut kebutuhan masyarakat terhadap pelayanan penunjang kehidupan pun sangatlah tinggi seperti akses masyarakat mendapatkan pendidikan dan kesehatan. Tingkat pendidikan masyarakat petani sebagian besar tidak mendapatkan pendidikan yang cukup. Sebagian masyarakat petani di Kecamatan Bandar merupakan petani yang hanya memiliki tingkat pendidikan sekolah dasar ataupun tidak bersekolah, hal tersebut ditunjukkan oleh besaran angka indeks pendidikan 0-1 seperti Gambar 5 berikut ini:

Gambar 5. Peta distribusi spasial indeks pendidikan di Kecamatan Bandar (Analisis Penulis, 2014)

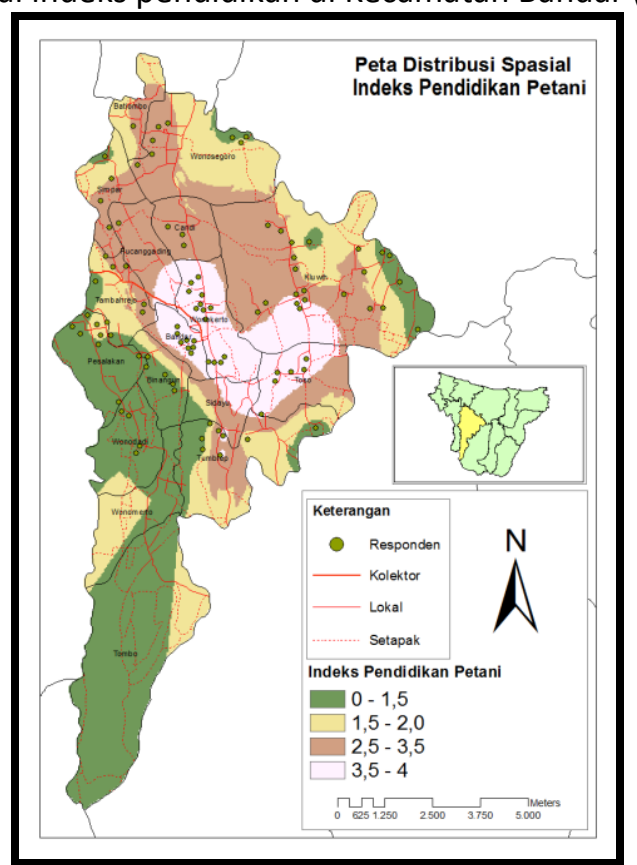




\section{c. Modal Sosial (Sosial Capital)}

Di Kecamatan Bandar hal yang paling terasa dalam membangun interaksi sosial oleh para petani adalah pada saat terjadinya sengketa perebutan lahan yaitu membentuk suatu paguyuban. Namun fungsi dari paguyuban maupun organisasi ataupun perkumpulan masyarakat lainnya tidak merambah kepada peningkatan mutu dan hasil dari pertanian itu sendiri. Minimnya transfer informasi mengenai peningkatan hasil pangan dan penghasilan menjadi hambatan sosial yang dialami bagi sesama masyarakat petani Kecamatan Bandar.

\section{d. Modal Fisik (Physical Capital)}

Livelihood merupakan istilah pembangunan sehingga modal fisik merupakan salah satu modal penunjang kehidupan masyarakat yang berbentuk dan tampak serta dapat diukur langsung keberadaannya. Akses yang lebih baik terhadap fasilitas umum dan penunjang kehidupan diukur untuk melihat sejauh mana masyarakat memperoleh infrastruktur dasar yang membantu mendukung mata pencaharian. Termasuk didalamnya alat infrastruktur seperti jalan, air, listrik serta fasilitas pasar (dalam artian luas) ataupun fasilitas kesehatan dan pendidikan yang akan mempengaruhi kemampuan orang lain untuk mendapatkan kehidupan yang layak.

Tabel 2. Kondisi modal fisik penunjang permukiman di Kecamatan Bandar (Analisis Penulis, 2014)

\begin{tabular}{|c|c|c|c|}
\hline $\begin{array}{l}\text { Indikator Fisik } \\
\text { Penunjans } \\
\text { Permukiman }\end{array}$ & $\begin{array}{c}\text { Kondisi df Kecamatan Bander } \\
\text { (Kecamatan Dalam Angke Dan } \\
\text { Otservasi) }\end{array}$ & $\begin{array}{l}\text { Hasil Dari } \\
\text { Responden } \\
\text { (Kuesioner) }\end{array}$ & Keteranean \\
\hline Kondisi Jalan & $\begin{array}{l}\text { Sebagian besar jalan beraspal. } \\
\text { Jalan mulai berlubane dan } \\
\text { betastuan bila memasukiangialan } \\
\text { pedesaan dan daerah tinegi. }\end{array}$ & $\begin{array}{l}76 \% \text { mengatakan } \\
\text { jalan beraspal } \\
\text { meniangkauhingga } \\
\text { depan rumahnya } \\
\text { dan sisanya } \\
\text { mengatakan tidak. }\end{array}$ & $\begin{array}{l}\text { Walaupun topografi } \\
\text { Kecamatan Bandar berupa } \\
\text { perbukitan namun kondisi } \\
\text { jalan } 758 \text { baik untuk. } \\
\text { digunakan. }\end{array}$ \\
\hline $\begin{array}{l}\text { Jarak Pasar - } \\
\text { Permukiman }\end{array}$ & $\begin{array}{l}\text { Pasar utama berada ditengah } \\
\text { Kecamatan Bandar vaitu di } \\
\text { Kelurahan Bandar }\end{array}$ & $\begin{array}{l}91 \% \text { mergatakan } \\
\text { kebutuhan } \\
\text { ekonomi sehari - } \\
\text { hari dapat } \\
\text { diperoleh di } \\
\text { Kecamatan Bandar }\end{array}$ & $\begin{array}{l}\text { Pasar dan beberapa daerah } \\
\text { pertokcan berada di pusat } \\
\text { keccamatan yaitu di Kelurahan } \\
\text { Bandar dan sekitarnya. } \\
\text { Aksesnya pun tidakiah sulit } \\
\text { sehincga menvebabian } \\
\text { kemudahan kegiatan } \\
\text { perekonomian. }\end{array}$ \\
\hline $\begin{array}{l}\text { Kondisi } \\
\text { Tempat } \\
\text { Tinegal }\end{array}$ & $\begin{array}{l}\text { Terdapat } 37 \% \text { rumah permanen, } \\
\text { 38\% semi permanen dan } 25 \% \\
\text { rumah sederhana }\end{array}$ & $\begin{array}{l}\text { Hasil dari } \\
\text { responden adalah } \\
\text { terdapat } 31 \% \\
\text { rumah permanen, } \\
49 \% \text { semi } \\
\text { permanen dan } 20 \% \\
\text { rumah sederhana. }\end{array}$ & $\begin{array}{l}\text { Rumah sederhana di } \\
\text { Kecamatan Bandar tidak } \\
\text { dapat dikategorikan kumuh. } \\
\text { Rata - rata tiap rumah } \\
\text { memiliki pekarangan, jendela, } \\
\text { berdinding kavu tebal dan } \\
\text { tidak berdempetan satu } \\
\text { dengan lainnya. }\end{array}$ \\
\hline $\begin{array}{l}\text { Ketersediaan } \\
\text { Air Bersih }\end{array}$ & $\begin{array}{l}\text { Jangkauan pamsimas berada } \\
\text { dipusat kecamatan hingga } \\
\text { kebagian utara, belum menjangkau } \\
\text { daerah pedesaan. Sebagian } \\
\text { menggunakan air sumur dansungai }\end{array}$ & $\begin{array}{l}\text { Terdapat } 22 \text { orang } \\
\text { vang mengaliri air } \\
\text { sungai untuk } \\
\text { kebutuhan sehari - } \\
\text { hari, } 48 \\
\text { menggunakan air } \\
\text { sumur dan } 29 \\
\text { menggunakan air } \\
\text { dari PAMSIMAS }\end{array}$ & $\begin{array}{l}\text { Terdapat sarana air bersih } \\
\text { dari pemerintah namun } \\
\text { belum menjangkau hingga ke } \\
\text { daerah yane lebih dalam. } \\
\text { Keberadaan sumberdaya } \\
\text { alam yang boik menvebubican } \\
\text { kebutuhan air masyarakat } \\
\text { dirasa cukup maksimal. }\end{array}$ \\
\hline $\begin{array}{l}\text { Ketersediaan } \\
\text { Utilitas } \\
\text { Umum Dan } \\
\text { Fasilitas Sosial }\end{array}$ & $\begin{array}{l}\text { Terdapat } 114 \text { fasilitas olahraga, } 92 \\
\text { fasilitas kesehatan, } 102 \text { fasilitas } \\
\text { pendidikan dan } 1055 \text { fasilitas } \\
\text { ekonomi oi Kecamatan Bandar }\end{array}$ & $\begin{array}{l}\text { Semua masyarakat } \\
\text { petani merasakan } \\
\text { bahwa pelayanan } \\
\text { utilitas umum dan } \\
\text { fasilitas sudah } \\
\text { maksimal. } \\
\text { Keberadaan sarana } \\
\text { prasarana tersebut } \\
\text { sudah menjangkau } \\
\text { masyarakat }\end{array}$ & $\begin{array}{l}\text { Dengan jumlah dan } \\
\text { kepadatan penduduk di } \\
\text { Kecamatan Bandar terhadap } \\
\text { sarana prasarans sosial } \\
\text { permukiman keberadaannya } \\
\text { sudah terpenuhi secara baik. }\end{array}$ \\
\hline
\end{tabular}




\section{e. Modal Finansial (Financial Capital)}

Merupakan sumberdaya pembiayaan finansial baik yang dijadikan modal awal pembiayaan kegiatan atau aktifitas pertanian, pemenuhan kebutuhan sehari - hari maupun dana yang diperuntukkan sebagai modal pembuka usaha baru. Dalam kegiatan pertanian tentu saja sumberdaya finansial dimanfaatkan sebagai modal untuk melakukan kegiatan penanaman, pemeliharaan, dan panen yang berasal dari tabungan dan hutang. Berikut merupakan alur penggunaan sumberdaya finansial masyarakat petani dapat dilihat pada Gambar 6 berikut ini.

Gambar 6. Alur penggunaan sumberdaya finansial petani Kecamatan Bandar (Analisis Penulis, 2014)

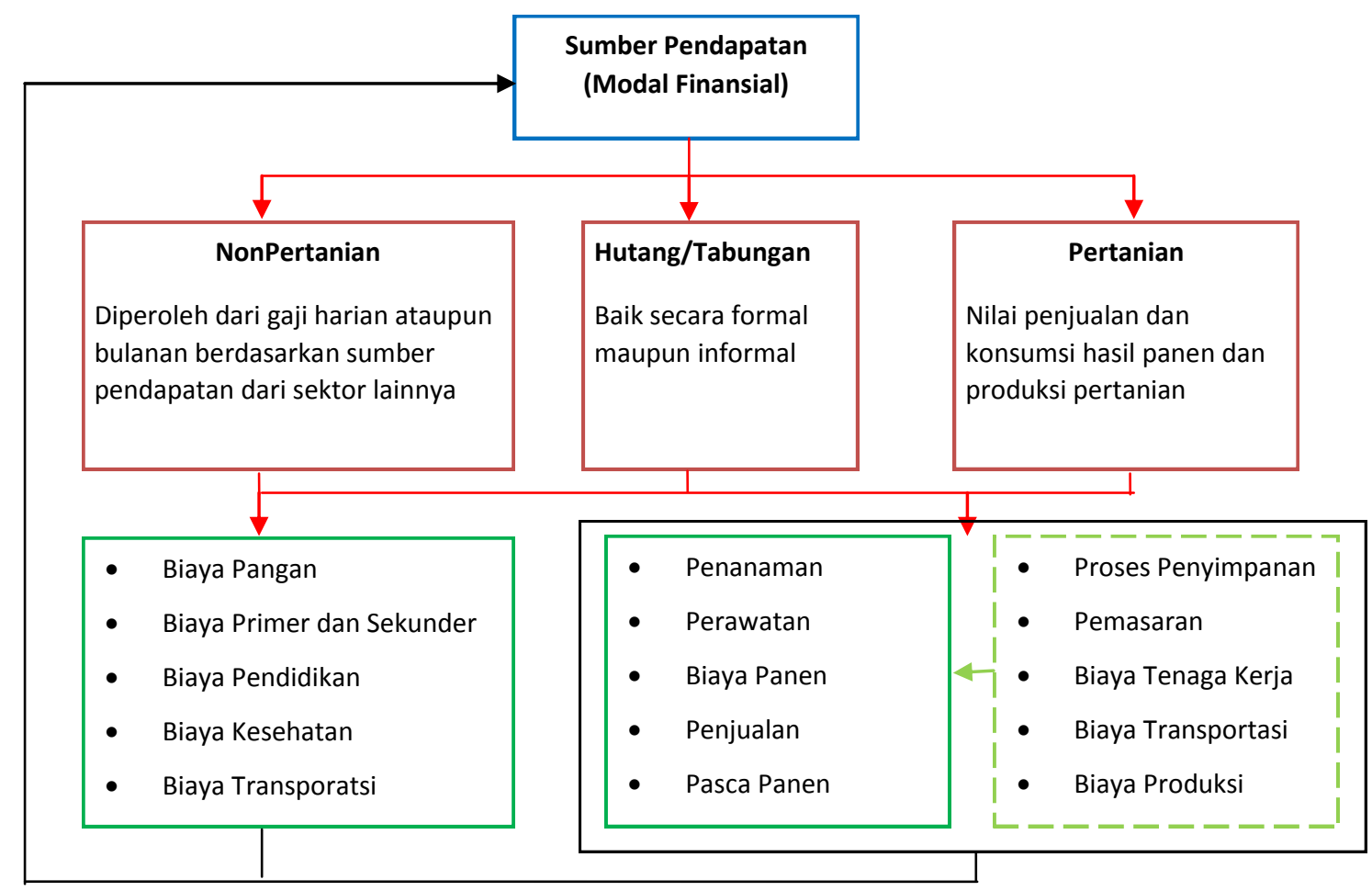

\subsection{Penghidupan Berkelanjutan (Sustainable Livelihood)}

Output dari hasil analisis ini adalah berupa tingkat penghidupan berkelanjutan (sustainable livelihood) di Kecamatan Bandar dengan tingkat penghidupan keberlanjutan diperoleh dari akumulasi tingkat kelima aset livelihood (sumberdaya alam, sumberdaya manusia, modal fisik, modal sosial dan modal finansial) dimana diasumsikan dengan hasil yang diperoleh dari kuesioner dan observasi terhadap responden baik berupa data primer maupun sekunder. Untuk mempermudah perhitungan metode pendekatan kuantitatif maka digunakan perhitungan skoring dengan masing -masing nilai dicocokkan dengan kriteria penilaian yang ada (berdasarkan hasil dari kuesioner) sehingga penilaian terhadap total skor antara lain dapat diketahui seberapa besar nilai maksimal akses atas aset di Kecamatan Bandar. Adapun penilaian untuk data yang dihitung dari masing - masing variabel dapat dilihat pada tabel sebagai berikut.

Tabel 3. Tingkat penghidupan berkelanjutan di Kecamatan Bandar (Analisis Penulis, 2014)

\begin{tabular}{|c|c|}
\hline Variabel & Nilai Skor Total \\
\hline Sumberdaya alam & 1050 \\
\hline Sumberdaya manusia & 1543 \\
\hline Modal finansial & 599 \\
\hline Modal sosial & 593 \\
\hline Modal fisik & 1266 \\
\hline
\end{tabular}




\subsection{Pentagon Aset Livelihood}

Pada dasarnya petani miskin ditandai dengan keterbatasan akses masyarakat pada aset-aset yang ada, dimana di gambarkan pada pentagon aset titik tengah/pusat menunjukkan angka nol sementara batas luar nilai tersebut menunjukkan akses maksimum yang mampu diperoleh pada aset-aset tersebut.

Gambar 7. Pentagon aset kondisi Suistanable Livelihoods (Analisis Penulis, 2014)

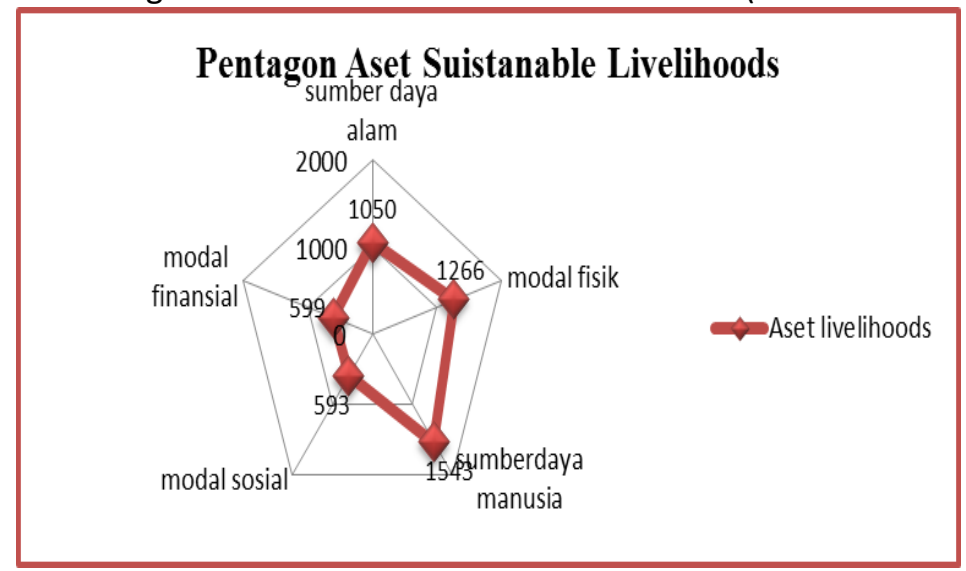

Berdasarkan dari hasil Gambar 7 diatas maka dapat di ketahui penyebab kemiskinan yang terjadi di Kecamatan Bandar dikarenakan lemahnya akses masyarakat terhadap aset/modal finansial dan sosial. Keberadaaan sumberdaya manusia yang baik, didukung dengan adanya modal fisik dan sumberdaya alam yang kuat tidak menjadikan masyarakat petani memiliki penghidupan yang layak atau positif dan berada dilingkaran kemiskinan.

\section{KESIMPULAN}

Dalam sistem Livelihood terdapat lima aset penghidupan dimana kekuatan akses maksimal dimiliki oleh sumberdaya manusia, selanjutnya diikuti dengan modal fisik dan modal sumberdaya alam. Sedangkan kondisi dua aset lainnya yaitu modal finansial dan sosial hanya memiliki nilai yang kurang maksimal/rendah. Hal tersebut ditandai dengan rata - rata tiap anggota keluarga berpendapatan perkapita Rp. 5.399.345 pertahun atau berada dibawah standar penghasilan Kabupaten Batang, sebagian besar petaninya berpola subsisten atau tidak menjadikan pertanian sebagai ladang komersial dan kurang berfungsinya kelompok sosial secara baik membuat rata - rata masyarakat petani berada dibawah garis kemiskinan.

\section{DAFTAR PUSTAKA}

FAO.2008.Socio-Economic And Livelihood Analisys In Investment In Planning.

Sapa.2011.Promoting Innovation, Coordination And Participation In Poverty Alleviation Programs. Saragih, dkk. 2007. 2390_SL-Chapter1 Kerangka Penghidupan Berkelanjutan (Sustainable Livelohood Framework).

Sri Saadah Soepono, et al.1995. Corak dan Pola Kehidupan Sosial Ekonomi Pedesaaan: Studi tentang kewiraswastaan Pada Masyarakat di Plered, (Jakarta: Proyek Pengkajian dan Pembinaan Nilai-nilai budaya Direktorat Sejarah dan Nilai Tradisional Direktorat Jenderal Kebudayaan):hlm 1.

www.SuaraMerdeka.com.2011. Redistribusikan Tanah.Desember.diakses pada tanggal 17 juni 2012. 